\section{THE DEATH PENALTY}

\section{Preecha Changkhwanyuen ${ }^{1}$}

\begin{abstract}
The objective of this research is to find out how Thai academics conducting studies on the question of punishment and practitioners of work related punishment view the issue. The study relies on methods of literature review and brainstorming seminars, divided according to disciplines, and collectively as a general lecture forum. Thai academics participating in the seminar with backgrounds in law, philosophy and religion or political science presented views that were in conjunction with the findings of the research presented culminating in a number of suggestions concerning the necessity and importance of capital punishment as well as its moral and justice aspects.
\end{abstract}

Capital punishment so far has been considered the best method but it is merely a final solution when a crime has been committed. Reforms in the justice system and education that aims at uplifting the spiritual and emotional wellbeing of the people are needed so as to reduce the impetus leading to capital punishment.

Consideration of the issue of the death penalty from the academic viewpoints of Buddhism, Political Science and Law has yielded congruent ways of thinking and analysis i.e. that it should continue for the following reasons:

\footnotetext{
${ }^{1}$ Professor, Department of Philosophy, Chulalongkorn University
}

\section{Reasons for the Death Penalty}

Penalties occur when human beings evolve into social beings and may be considered a social activity. Physical attacks against other people 'are' assaults but not punishments. By the same token, the assaulted person's retaliation in a similar or more violent manner isn't a punishment but an act of revenge. Social punishment is neither a retaliation nor an act of revenge. It is not the same act as that of a friend or relative of the assaulted party avenging a loved one since society does not impose punishment as an emotional response. This is the case, most especially, in societies governed by principles prescribed by the law or the state. The state's act of imposing punishment is the execution of the law and not any form of vengeance. A judge isn't acting out of vengeance but simply imposing a sentence according to the evidence and legal prescription without discrimination.

\section{Reasons for Punishment According to Buddhist Thinking}

A vital Buddhist sutra - the discourse or original sermons of the Lord Buddha -demonstrating Buddhist thinking on the subject of punishment is the Akkanya Sutra. It alludes to the Buddha's declaration that in the early stages of human existence, human beings were not yet familiar with evil or wrong doing. This familiarity entered into human consciousness when innocence weakened and evil could take over, causing greed and avarice that led to accusations, lies, physical assault and revenge. Perceiving this situation, the senior members of society in their wisdom deemed it time to 
curtail such vile acts. These deeds would ultimately bring about nothing but strife, with the problem being that in such situations no one would admit to wrong doing nor could it be decided who was guilty. Consent was given so that "by supposition one person should be accorded the task of rightfully reprimanding a person deserving reprimand, admonishing a person deserving of admonishment and rightfully driving away a person deserving of being driven away.'

This viewpoint attests to the fact that rightful punishment is a form of punishment that society sanctions and that the person rightfully accorded the power to impose punishment is a representative selected by society to perform the task. The said person is therefore not performing a 'personal' act but is acting as representative of 'the whole' and is totally devoid of the 'personal.' The penalty involved includes lenient punishment for minor offenses that might result in only a reprimand, heavier punishment that demands admonishment, and severe punishment that necessitates the exclusion of the wrongdoer from society by way of banishment or exile. The leniency or severity of the punishment conforms, therefore, to the severity of the offense committed. Since it is devoid of personal emotion, it is not a form of revenge as the vengeful person is not the one executing the penalty and the conduct of the one executing the punishment is acting out of concern for the welfare of others. The penalty is acted out with impartiality by an agent in a manner proportionate to the offense.

The concept behind this punishment is to see that the person committing an offense performs an act of retribution; it is not simply to satisfy the person who is the victim of that offense, who would naturally demand a punishment stronger than that which the offender deserves. It is in fact a penalty that is reasonable in terms of the offense, and the punishment is in accordance with social judgment which is impartial to the crime or offense committed.

From a political science perspective, punishment is a mechanism employed by the state to dispense justice to both parties whenever an offense occurs. Fairness or justice is obviously gratifying to the complainant since the perpetrator has been adequately made to suffer the consequences. This is especially so in cases where a person is not in a position to take revenge. Punishment also causes fear which decreases the incidence of offenses within the state especially those that are committed intentionally. This results in a peaceful state that is able to develop without the hindrance of offenses committed by its citizens.

From the legal perspective, administrators who follow the law are obviously seen as not indulging in personal feeling or emotion. At the same time the law is a principle that has received prior announcement. The reinforcement of the law is thus a way of conforming to mutually accepted regulations, and the law must also be something that is accepted by the entire population. Although the Akkanya Sutra does not refer specifically to the law, if one were to consider the various states that have existed in the past, even those ruled by an absolute monarch, all clearly adhere to the law. This is because, even under such rules of absolutism, though the power of the people is not represented, for legitimate rule 
the dhamma of government must still be used. What is stated in religious scriptures is used to support that legitimacy and the scriptures are then used as a legal document for governance. Otherwise there has to exist a law that is congruous or at least does not contradict the scriptures in order for the leader to maintain his position as head of state.

In terms of karmic justice, state rule is a social mechanism that enables karmic justice to be executed within this reincarnation. It is a mechanism whereby a person is punished by his/her earned evil karma due to the fact that he/she has made the choice of committing the karma that might result in punishment in accordance with this mechanism. Once he/she has received punishment, if the karma is still incomplete, then he/she will have to endure punishment in the future or in other subsequent reincarnations.

According to this argument, a person receiving punishment from the state is actually being punished by his/her own karma. This applies even to those who are punished by a faulty system of justice where the explanation is that it is their own karma that causes the punishment even though they have not committed an offense. By the same token, those involved in the state's mechanism that have caused the enmity cannot be liable since there is no personal intention involved.

\section{Reasons for Punishment According to Democratic Thinking}

The principles of free democracy that are presently valued and adhered to derive mainly from the ideas of John Locke and begin from the premise that human beings in their natural state devoid of society all enjoy a status of total equality. It is also human nature that there are times when the person suffering in a struggle is unable to retaliate or other times when he/she retaliates with a severity that is stronger than the offense. This vengeful retaliation can cause such turmoil that society cannot function peacefully. Even though such a state may be legitimate, ultimately, violations of rights will occur and those absolute rights will cease to be meaningful.

Endowed as they are with intelligence, human beings can perceive that when such cases prevail the solution is to sacrifice some of their rights by committing themselves in mutual agreement to abandoning their rights and conforming to a regulatory framework that will ensure a society that avoids turmoil. This form of power derives from the rights sacrificed by the people and this is the source of state power.

From this perspective, it is precisely this power on the part of the state that enables our rights by nature to be implemented in actuality. The basis of this premise is that the people are entitled to the highest form of rights in the state and the power of the state is none other than the mutual rights enjoyed by the people. The execution of power by the state within the said covenant is therefore not a form of human rights violation; in other words, it is a violation of human rights within a legitimate legal framework. 
Evoking the concept of human rights under the pretext of not allowing the state to execute its power within a legal framework is merely arguing from an individual perspective. It is a right that exists in our natural state yet, in effect, within that condition human beings are unable to truly use or receive those rights. Such a condition is even more of a violation than within the statutes of the state. In the latter case, humans are accorded the remaining rights since the proportion is attached to the power of the state, which is equated to human rights in their entirety. Democratic rule entails the willing allocation of rights, and it is the people who are involved in the state's execution of those rights or administrative powers themselves. It is self-rule with one's own rights and with oneself as ruler. Within the framework of political and government ethics the individual can therefore not be entitled to evoke absolute human rights as an excuse and claim that the state is violating what has been naturally prescribed since he/she has already consented to that mutually agreed covenant.

Evoking the concept of human rights, whether it be in cases concerning life, thinking or any action whatsoever, under that pretext is not valid. Since punishment in whatever form would obviously be considered a form of physical or mental violation and therefore must not be permitted. Indeed doing so would be tantamount to doing away with the laws and the authority of the state, and returning man to his inherent natural state, which is even worse. Democratic rights which place greater emphasis on personal rights than any other political rights, therefore, insist that the state must maintain its governing power.
This power is not anything other than the autonomous power belonging to the people, deriving from the people and used by the people openly for the people themselves. How can self government or self punishment be interpreted as a violation of one's own human rights? Civil rights can only be truly meaningful when they can actually be used. As a mere concept in its natural form, how can they be of value? The best scenario for the successful implementation of human rights is therefore in a democratic state.

Punishment must remain a feature of the democratic state in order to protect the human rights of individuals as citizens of the state. It must protect the state from violating the rights of its citizens and protect its citizens from violating the rights of other citizens. When imposing punishment, the state must therefore be mindful of the rights of its citizens equally, seeing to it that it is imposed in order to do justice to the party whose rights have been violated. If and when the punishment imposed is unreasonably severe or of questionable legality this will mean a violation of the rights of the perpetrator and justify the perpetrator's demands for justice so as to avoid that violation. Aside from not being a violation of rights, punishment is also imposed so that human rights can indeed prevail. If the state gives priority to the rights of the violator, it is in effect disregarding the violated party who should in fact be receiving justice. Nevertheless, this might elicit an argument such as this :

Human rights are therefore the basic rights since all human beings are entitled to equal treatment without discrimination in such 
things as gender, skin color, race or religion. This concept should apply as well to the offender whose treatment should conform to the dignity accorded to him/her as a human being. To many, the concept of human rights may be perceived as a means to protect the defendant as well as reprisal for the victim. In actual fact, the principles of human rights aim at a just treatment for all members of society. Nevertheless, for those supporters of capital punishment who think that if a person has destroyed another's life then he/she deserves to lose his/her life in retribution, the argument might appear to be sound It is, however, difficult for me to accept this on the basis of the principles of human rights which determine that the state must provide humane treatment to the offenders and if any punishment is involved it must not involve acts of viciousness or brutality that result in physical harm or danger or cause mental or physical suffering. For this reason, capital punishment which translates as the destruction of the life of members of society by the state is a severe violation of the principles of human rights despite the fact that these nen may be wrongdoers (Witthaya Suriyawong, 2004:2).

A point that might be taken into consideration in the aforementioned argument is that the basis employed for the term human rights is the assumption that all men are created equal, a point one can readily accept. Nevertheless, the difference lies in the fact that human beings perform both good and evil deeds. Employing the principles of human rights equally to both the virtuous and the evildoer ostensibly attests to the fact that the principle is biased in placing equal importance on matters that are disproportionate. In order for the principle of human rights not to be corrupt, these rights should be accorded to the side of virtue and not evil. This general way of thinking is a natural assumption for right or wrong. It is this principle of justice that necessitates the use of intellectual consideration in its consideration.

Human rights advocates often are discriminatory and selective in their views. The perception or consideration of matters related to human beings from their perspective should thus be seen as one isolated viewpoint, if indeed a necessary and valid one. We all know, however, that an issue can be perceived from different standpoints, and even from the human rights standpoint there are diverse ways of considering the matter. Seeing the wrongdoer as the only party worthy of human rights is in effect ignoring the rights of the person suffering from that wrong doing. It is a violation of the rights of others as well as a violation of the laws of the state. Upholding human rights as the sole argument is therefore tantamount to ignoring the rules of justice since the rights being espoused supersede justice itself.

This limited stance in approaching the issue is itself rather incautious. Approaching it discriminatingly is dangerous as well as biased even though some might argue that the bias is meant to benefit others. 


\section{The Death Penalty}

The problems surrounding the existence of said laws and penalties attest to the fact that their existence is legitimate when they conform to a process that itself enjoys legitimacy. The legitimacy of imposing a penalty is contingent upon imposing a punishment appropriate to the severity of the offense. This is a point that is seldom discussed. Indeed, what is a constant topic of discussion is whether or not the severest form of penalty should include the elimination of one's life and whether or not the state has the right to destroy the life of an individual.

In this issue, one must understand that a state would not pass such a law if there didn't exist those who commit serious offenses. The State does not have the decision to impose its power yet it is necessary to do so. One cannot deny that the existence of the penalty is an acceptance that compensation for wrongdoing is just whether from the point of view of the State or the individual. The penalty could be a reminder, an admonishment, the levying of a fine, the payment of a debt, incarceration, a flogging, performance of community service or even the death penalty. The point is that ultimately the penalty must not be imposed with vengeance and should not be more severe than the actual offense committed. For this reason, it is the state, in its impartiality, that needs to uphold the penalty.

Whether or not a life should be eliminated as a form of retribution or debt repayment is a matter that can be considered from a myriad of viewpoints. For the purposes of this discussion, the issue as to whether it is legitimate will be considered.

A penalty is the act of giving the offender what he/she least desires as a response to a violation against others. The penalty need not conform exactly to the initial violation; for example, the act of cheating does not necessitate being cheated since a penalty isn't form of revenge. A person who receives a prison sentence isn't being imprisoned because of having imprisoned another individual. A person who covets wealth and riches and who has a fine levied will find it undesirable; the fine is therefore a penalty. A person who values freedom will find incarceration undesirable and that incarceration is therefore a penalty. Pain and suffering are what most people fear and therefore can be used as a penalty. By the same token, life is what human beings value most, which is why execution can be used as a penalty.

In the same way that offenses vary in severity, the severity of a penalty depends on the seriousness of the offense. If the offense concerns the elimination of another person's life, that which is most valuable to that person, the perpetrator should compensate with the life that he/she most values and therefore there is no other punishment more suitable than the death penalty. However, the destruction of a person's life does vary from cases involving those who destroy the lives of others for personal benefit or mere satisfaction despite the fact that their victims have never caused any personal grievance to cases where there is an actual cause of grievance inviting the destruction of that person's life. In the same way that the death penalty should not be 
uniformly imposed, all cases should not be uniformly absolved from the penalty.

If only it were the case that society consists only of members who are moral and virtuous. Then all crimes could be assumed to have been committed out of carelessness or without intention or in extreme circumstances beyond one's control and the death penalty might not be required. In such cases, the person suffering damage might not feel that carelessness or extreme circumstances warrant the taking of another person's life. Unfortunately, this does not apply in the case of most societies. Violations of other individuals' lives and property are often intentional and premeditated. The offense committed can be so severe that society deems it proper to impose the death penalty, and if that is not done, then some other penalty must be imposed to compensate adequately for the wrongdoing. In the latter case, that society must find a penalty adequately severe as compensation for the death penalty.

That the state should offer humane treatment to its offenders is acceptable as long as it conforms to the offense committed. Humane treatment is, however, befitting only to human beings whose humanity is measured in terms of the level of moral wellbeing. Those who have committed despicable acts of evil may possess human physical features yet demonstrate a moral character worse than that of an animal. For this reason, there are words that characterize these vile actions as 'brutal to the point of being inhuman' or 'a bestial act.' A righteous act should be that which conforms to the level of character, for example, we have respect for the rights of others and curtail only the rights of those who have committed wrongdoing with penalties such as imprisonment. We express reverence for those whose spiritual wellbeing exceeds that of our own. Such examples are those in a religious order who conduct themselves in a righteous manner. A careful adherence to the principles of human rights should give due consideration to these matters.

Buddhist scriptures differentiate mankind according to the levels of their moral wellbeing roughly as Manussapeto- man who demonstrates the qualities of a demon, Manussatiratchano- man who demonstrates the qualities of a beast, Manuusa Manuso man who demonstrates the qualities of a human being and Manussa Thevo-man who demonstrates the qualities of a divinity. In actual fact, human beings do fall into such categories. They might be equally human yet demonstrate the qualities of being human differently. Treatment of human beings who are different should therefore be imposed differently. This applies equally to the treatment of beasts that can be cruel or tame. While we may treat them in a humane manner, the treatment can still be different. We may not execute a tiger that kills a human being since it is merely a beast whose actions are irrational yet we will need to lock it up to prevent it from harming people. Human beings, who are endowed with reason yet perform savage acts comparable to that of the tiger's deserve an even more severe form of punishment since there is no case for pardon as in the case of a tiger, which is a beast.

The concept of applying punishment that does not involve any emotional or physical torment is also impossible since mere 
imprisonment is a physical torment while a fine is an emotional torment. This particular concept does not give any clear definition of what constitutes torment, especially mental or emotional torment. Indeed, do the punishments imposed in countries where the death penalty has been abolished not involve any mental or physical torment? The principles of human rights that go against general common sense and show no sympathy for the victim and his/her loved ones forced to endure pain and suffering is probably the reason why the abolition of the death penalty has not happened in about half of the world -- this, discounting the fact that the argument is being exploited for economic advantage by several of the more powerful countries in the world.

Time and again we hear the claim from human rights activists that the death penalty is a severe violation of human rights. However, if one were to consider the issue from all its sides, one would see that the principle does not conflict with the concept of a death penalty as may be argued in the following:

Human rights are a personal form of ethics which occurs naturally and must not be violated. Nevertheless, the use of these rights must be limited so as not to affect the rights of other individuals. Liberal use of one's rights eventually leads to the violation of the rights of others. For this reason, laws exist so that clear demarcations can be defined, thus preventing violations. Ideally every person possesses rights and should be entitled to extensive use of those rights. Yet in reality the best scenario is the limiting of everyone's rights and usage of their rights.
Human rights activists are wont to take literally the interpretation of the concept they espouse and fail to ponder its true meaning. When human rights issues are related to matters of the state, the concept of rights as belonging to the individual and therefore inviolable emphasizes the individual's human rights purely from the perspective of the individual. This view is indeed idealistic since in reality the violation of rights constantly takes place, even when state power exists as protection. The idea is compounded if one were to consider man in his natural state in the same way as Locke or other social theorists do. In this state human beings cannot practically maintain any of their rights and it could be said that those rights exist mainly in theory.

The death penalty is no different from other penalties as it involves a violation of rights by the state. Penalties and punishments are a way of preserving one's rights as much as possible not through targeting the rights of any one individual in particular but collectively for all members of the state. For this rationale, one should revert to the words of Rousseau, who opined that 'the community does not have the right to execute anybody since it isn't the community that gave birth to that person.' The community can have that right only if there is a consensual willingness to relinquish one's natural rights so that it becomes the supreme right of the state that surpasses that of the individual and is thus able to punish the individual. This power is imposed in the form of a law and the law seems not only to punish but also to grant benefits. Accepting the law means accepting both the benefits as well as the penalties as stipulated by the law. Rousseau might argue 
that relinquishing those rights should be done only when necessary and as little as possible. It should not, therefore, include the relinquishing of one's life since society should respect the individual's right to life. Such a rationale is based upon the universal principal of respect for the right to life i.e all persons including the person him/herself must comply with that. If a person seriously violates the right to life of another individual, it should be tantamount to the violation of the promise to respect the rights of others. However, within the state, the state cannot organize retaliation itself but must put the matter into the hands of the law and it must be a law that allows the state to seriously violate the rights of the individual as well. The death penalty is therefore a mechanism to protect rights so that the life of the individual is not violated. This notion is also erroneous since the state is not the biological parent of the individual. It merely plays a parental role in terms of affirming the validity of marriage, birth and citizenship that entitles individuals to be reared, educated, provided with employment and everything else in life in the same way that a parent would.

For the state, justice is a virtue that must be upheld over and above the human rights of an individual since it is justice that preserves the rights of all beings simultaneously. Any argument that uses the rights of the individual at the expense of justice which serves as the mechanism to protect the rights of all members of society is therefore false. For this reason, if the death penalty is just and if the majority of society still deems it to be necessary to ensure justice, it is therefore a mechanism to maintain human rights from the violent violations of the rights of others.
Without the penalty, then violations by that same token could continue to be perpetrated by that individual or others, which is tantamount to violating the rights of other members of society.

In Thailand the death penalty is never imposed arbitrarily and corresponds to the severity of the penalty. The notion of severity corresponds as well to prevailing social values at various times such as with crimes against the monarchy, for example. The notion of crimes against religion such as decapitating Buddha images could be intensely shocking at certain times and less severe at others. At one time amphetamines were not categorized as narcotics and the penalty was slight unlike today when they are regarded as a dangerous substance with severe penalties. The level of severity is indeed relative and determined by society. In extreme cases this might even necessitate a penalty that involves destruction of a life.

Consideration being given solely to the rights of the perpetrator of a crime without any regard for the reasons of the other side in the extreme can result in the refusal to permit any executions even when the crime is heinous. At the same time, the notion of allowing the liberal use of the death penalty and bypassing the justice system or having it as part of a faulty justice system is a notion at the other extreme. One side views life as sacred and untouchable, no matter how base or evil. The other sees life as totally meaningless and opts for the death penalty at all times being completely void of justice, mercy and compassion. Nevertheless, the death penalty, according to what is legally prescribed and democratically derived, does not follow extreme emotions as in the first 
case; it combines the principles of both logic and compassion with that of justice. This is the middle path that aims towards social justice. It is cautious and rational, impartial between the complainant and the perpetrator, weighing each side equally. Imposing the death penalty according to this principle is therefore cautious and rational, taking the middle path between the victim and the perpetrator and weighing both accordingly.

\section{Other Reasons for Arguing Against the Death Penalty}

Other reasons in the death penalty argument are usually factual and not simply principles created and defined to be used arbitrarily to decide what is right and wrong as in the case of the human rights argument. For the human rights argument to be acceptable to most people, it must be based on factual evidence. The same thing goes for the acceptance of the equal status of human beings from the political standpoint proposed by John Locke while not accepting other aspects. Several of the more admissable reasons to be considered in the death penalty argument that are about to be discussed derive from the aforementioned article.

\subsection{Results in terms of crime prevention}

Crime suppression is one objective of imposing a penalty. In arguments on the subject, statistics are often used as evidence to support the notion that the existence of the death penalty does not reduce the incidence of crimes. It is concluded therefore that the death penalty does not result in having any effect on preventing crimes of the same type. If this argument is admissable then it is tantamount to accepting that penalties other than the death penalty are also ineffective in crime prevention. Theories on crime prevention or suppression are therefore rendered useless since the time before the penalty can be imposed is often so long that people forget or else they do not learn about it if the news isn't publicized adequately. Examples are seen when the execution of a convicted rapist takes place and the next day a similar crime occurs in the province of Samut Prakan where the perpetrator shows no fear of the death penalty. The simple explanation is that those who are not aware are not likely to be fearful.

Another supporting reason is that the more lenient the penalty the sooner it can be imposed and the more effective the results in crime. prevention. If that is the case a harsh punishment imposed rapidly should be even more effective in suppressing crime. This was the case during the time when Field Marshall Sarit Thanarat was Prime Minister. Back then fires used to break out on the eve of Chinese New Year, sometimes as many as two or three in a day. It was common knowledge that arson was being committed to clear the failed business accounts of the ethnic Chinese minority in Thailand. However, when orders were given to execute the arsonists by firing squad at the scene of the crime, such fires ceased to take place. The same went for the prevalence of mobsters or gangsters who had wreaked havoc on innocent members of the public. Severe forms of suppression and harsh penalties subsequenlty rid Thailand of such criminal acts. 
It is an erroneous claim that the death penalty is ineffective when it comes to crime suppression especially in cases of severe crime since references are usually made to statistics of crimes that neither increase nor decrease as in the case of drug crimes. One might view it the other way, that the statistics remain unchanged due to serious suppression which means that the number of those arrested is bound to be higher. The imposition of the death penalty for drug charges has also significantly deterred drug trafficking. Information of this type is known mainly, however, in the communities and tends to present itself less in terms of research since it is highly improbable that drug dealers would disclose such information. Conversely, in the argument against the death penalty aforementioned if there did not exist serious suppression and penalization, one would expect that the number of both dealers and users of drugs would be much higher than shown in statistics. The number of dealers would, moreover, be lower. At least those who have been executed are unable to continue to traffic in drugs. With merely a jail sentence, they could establish drug trafficking syndicates from within their prison cells. Moreover, that the numbers do not show a reduction is also due to the fact that the numbers of those who have been executed and incarcerated are not included in the final tally.

In actual fact, even though the death penalty can only play a minor role in preventing crime, it shouldn't lead one to conclude that it should not exist since, after retribution for wrong doing, crime prevention is its second objective. If it fails to prevent crime then it should compensate for wrongdoing. If it succeeds, it can better support the argument in favor of the death penalty.

\subsection{Failure in the justice system}

Failures or errors in the justice system can occur and do indeed occur in all countries. This only argues that the process be corrected and not be used as a reason to abolish a penalty when it should be imposed so that a lesser punishment is given instead which would be an injustice for the violated person. The following is an example that attests to such a rationale.

'We all must accept the truth that errors can always occur within the justice system despite the fact of the existence of three courts as well as other legal preventive measures. Errors happen due to the fact that judgement is based on evidence presented by the officials in charge. We well recall the murder case of Miss Sherie Ann Duncan where errors occurred, errors that led to the destruction of the families of innocent victims who had been wrongly accused. Fortunately no executions had taken place for if this had been so, that would have led to tragic consequences. After public awareness had been stirred, it led to an outcry for reforms of the justice system that lasted briefly and the outcry soon fell silent.'

This statement, conveyed with emotion, is indeed an attestation to the fact that errors in the justice system can lead to the execution of innocent victims. However, from another perspective it is a clear indication of the carelessness in executing the process, which means that both the personnel and the process involved must undergo reform so as 
to ensure greater caution. It is clear though that even though this matter is of grave importance, resulting in significant public outcry, it has yet to receive the attention of all those involved. One realizes the matter is not beyond remedy and the public does not often learn of such errors often enough to move for changes as in the case earlier discussed. This is because those who are well aware of the mistakes are themselves involved in the process and these mistakes are not always revealed. This is even more so if those involved are those seeking changes are hard to find. For this reason, changes do not occur and the errors persist. Therefore, instead of aiming at solving the problem by abolishing the death penalty for the mere reason that attempts have not been made to remedy the justice system, measures should be taken to ensure that justice prevails and to seriously see to it that such mistakes are avoided.

\subsection{The dynamic nature of the law}

The penalties that society determines may change since society's definition of the level of severity can change as in the case of metah-amphetamines which were not categorized as narcotic drugs in the past but possession of which is punishable by death today. This has led people to think that the same crimes committed in the past or present are punished differently and that a crime resulting in the death penalty today may receive a less severe punishment in the future. In such a case there will be no way to commute the sentence of someone who has received the death penalty.

This argument could well apply to any other form or level of penalty and if so, then the law should cease to exist. Actually, before a law is enforced, there has to be prior announcement or promulgation. Members of society must conform to the conditions of not committing wrongdoing from the day a law takes effect. Those who might benefit from the new law could certainly enjoy that advantage. At the same time, those who have the misfortune not to benefit from it for reasons such as having served their full sentence or having already been executed can in no way be entitled to blame the newer law. At the same time, one must take into consideration the fact that even when a new law is announced and increases the penalty to a more severe level, those who have received a prior sentence also do not have to have their sentences increased. This sociological argument does not, therefore, merit legal consideration in as much as it is one that deals with perceptions and emotions.

3.4 The death penalty causes criminals to treat their victims and law enforcers in a more brutal manner.

This belief stems from the notion that if society uses the death penalty too lavishly, criminals will treat their victims more brutally in order to avoid being arrested. Cases such as rape or common theft could end in murder so as to silence the victims.

While this argument may sound logical, in actual fact rape and common theft are not usually punishable by death and criminals kill their victims for other reasons such as fear of being punished. This does not mean that the killing occurs out of fear of the death penalty. In the cases of drug pushers who kill those who have knowledge of their 
illicit activities, even in cases where a drug offense is not punishable by death, victims can still be killed. This is because an arrest could result in loss of money, incarceration and being deprived of the opportunity to be in the lucrative business of drug dealing.

In cases where the death penalty is not imposed, if the crime of killing another person is punishable by death why then would a criminal commit murder simply to end up receiving the death penalty? If being arrested does not result in the death penalty, would it not be the case that the death penalty should, in fact, protect victims from being murdered?

The death penalty should apply only to crimes that are intensely severe in nature. In such cases, if a severe punishment does not exist, people might be more easily motivated to commit a crime. If it is severe, the penalty must also be severe and this can lead to anticipation that the perpetrator will kill his/her victim. Such a fear that a criminal would kill the victim to the point of reducing the punishment so that it is lighter than the crime is tantamount to surrendering to the threats of a criminal. It would thus appear that the state is deficient in applying justice, and it is as if it is the criminal who is determining the conditions whereby the highest penalty cannot be the death penalty.

Crimes punishable with the death penalty should indeed be limited not because of fear of harsh treatment toward the victim but because the penalty is severe and should therefore be used only for extremely serious cases of which there are not that many types. Therefore, if the death penalty is suited to certain types of crimes, it should be retained no matter whether the criminals treat their victims in a more brutal manner. In Malaysia, where possession of illegal drugs or possession of firearms, is punishable by death, it does not appear that the crime rate has increased or that more criminals silence their victims by murdering them. In fact, Malaysia appears to be more peaceful than Thailand even.

3.5 The existence of the death penalty could pave the way to abuse of power by state officials.

Cases whereby officials employ their power in a wrongful manner in order to avail tlerselves of certain benefits or wrongful accusations could be rampant because the death penalty is such a severe punishment. People might feel so intimidated that they will pay huge sums to officials or wrongful accusations could result in the accused person receiving the death penalty. Nevertheless, if the death penalty were to be abolished simply for these reasons, such abuses of power or wrongful accusations would still continue to exist in the cases of other penalties. Does it mean, therefore, that other penalties should also be done away with?

Solving the problem by abolishing the penalty altogether is not correct. Those wrongful acts are wicked and unscrupulous and must be punished. A solution to the problem would be to impose an even more severe punishment when it involves abuse of power by demanding certain benefits or false accusations. Laws in the ancient times had such provisions whereby a member of the justice system or a civil servant involved or authorized to handle a case would receive 
a more severe sentence than that of a lay person.

Employing caution in order to avoid such situations is indeed commendable and amendments should of course be made. Yet, this argument appears to be like the others that have been discussed. These are not problems that cannot be solved as much as problems that continue to persist not because they are too complex to be solved but because adequate efforts have not been made.

\subsection{The death penalty is usually imposed on less fortunate members of society.}

'More than 95 percent of prison inmates are less fortunate members of society. They are mostly indigents with only a primary education -- the underclass of society. Whether or not these people are guilty of an offense, they have hardly any chance when it comes to standing on trial. Some are lured into confessing to the crime in order to reduce their sentence or even worse are forced to make a confession. It is sad that these people are given the death penalty since they are the less fortunate who lack the opportunities, knowledge and economic wherewithall to seek justice for themselves.'

This statement and several other reasons cited earlier are minor features of a greater problem which is the defective justice system that leads to punishments that are unjust as well as unequal. In effect, this leads to the destruction of the justice system. Whether it is the death penalty or any other penalty, in a defective justice system penalties of all types will not be just. It is the system that should be amended for all the problems it causes. Indeed, if the justice system cannot guarantee justice, to whom can the people turn? If the system is faultless or the least faulty possible, then even the harshest penalty can be just.

\section{Concepts Regarding the Death Penalty from the Perspective of Thai Academics}

Most of the points discussed help us to understand the concepts regarding the death penalty and the reasons that have led Thai people, whether the general public or academic circles, to agree that it should continue to be maintained. Some of these perspectives are:

4.1 The death penalty differs from killing. The latter indicates the brutality of the killer while the death penalty signifies justice. Killing is a savage act whereas the death penalty is civilized. Those who fail to differentiate between the two are barbarians who are too uncivilized for more sophisticated thinking. A society that is able to make this differentiation is truly a civilized one. It shows an elaborate development of thinking when killing can serve as punishment in the same way as human beings who know not only how to use knives as weapons for killing but can derive some benefit out of using them even though in the two cases blades are used to cut and slice.

4.2 Those who do not use the death penalty are in no way just or merciful people. Instead they are cruel since they can see a person killed and are still able to sympathize with the killer. Those who side 
with killers must be very cruel to the victim since their sympathy is equal to tormenting the victim's loved ones even more.

4.3 The death penalty as it is enforced today is indeed merciful. No matter how cruel or torturous the killing or manslaughter had been, the state is still merciful enough to see to it that their execution is carried out with the least suffering and without torture. This is how civilized human beings act since the state has shown sympathy as well as respect for the condemned's dignity as a human being up until the final moment. This, despite the fact that their doings were brutal or even beastly.

4.4 The death penalty is not imposed in order to seek vengeance. From a political scientist's point of view the state does not use punishment with vengeance. It uses executions without bias and emotion.

4.5 In terms of Buddhist beliefs, if humans do not commit wrongdoing, then they won't be punished since that would be unjust. Penalties are imposed as a result of a person's own actions. One's deeds and one's punishment conform to the deeds one has committed. When it imposes a penalty, the state sees to it that it is equivalent to the crime committed. If the crime isn't severe then it would not merit the death penalty. If this weren't a civilized society then such perfectly adequate punishment could not be imposed in the same way that an inexperienced tailor could not sew a garment that is a perfect fit. The death penalty is a punishment that is appropriate to a crime. By avoiding it or imposing a penalty, one is imposing a penalty which is unjust. The death penalty should therefore continue so that justice can also be preserved.

4.6 The death penalty is not a sign of barbarism. The existence of the penalty does not attest to a barbaric state in the same way that its absence is not an indication of a civilized state. The use of the death penalty for cases of wrongdoing that are too severe to merit any other penalty demonstrates that a state is so civilized, it can differentiate the severity of the crime and ensure the highest justice.

As for the argument that life imprisonment causes more suffering than a death sentence, while this may be true to a certain extent, it is not related to the death penalty, which does not aim at causing suffering. It is simply the highest level of penalty, and means that the opportunity to exist in society is taken away for ever. If a penalty reflects a desire to impose suffering then ancient forms of torture such as those which appeared in the Phra Iyakan Krabod Suk would still be in existence. But they were special forms of penalty that did not apply to the average citizen and penalties imposed today are not imposed to make the person suffer; instead, suffering is constantly being reduced. Prisoners' welfare, for example, is now stressed so that they now are not subjected to the kind of squalid prisons that the French colonial officers used for incarcerating Thai inmates in Chantha Buri. If the death penalty did not exist and such forms of torture were used, this treatment would be more uncivilized. The argument that life imprisonment causes more suffering is therefore rooted in ideas that are far more uncivilised than those that consider the death penalty as the highest form of punishment 
that does not aim to cause suffering on the part of the perpetrator.

4.7 The death penalty guarantees justice for society and is merciful towards the people. The death penalty is carried out according to the principles of a justice system that society must maintain in order to ensure its peace and order. The perpetrator must be penalized according to the severity of the crime committed. The highest conforms to the most severe crime when it is deemed that the perpetrator should never have the chance to exist in society any longer while a more lenient form is a life sentence, the harsher sentence is the death penalty. If this form of punishment did not exist, the result could be that the perpetrator would receive a sentence that is too lenient.

In most cases the death penalty is imposed for crimes perpetrated against a life. For this reason, many people think that the penalty is a form of the seemingly vengeful law of lex talionis (an eye for an eye, a tooth for a tooth). In actual fact lex talionis itself isn't about vengeance since the victim or the side of the victim isn't the one imposing the penalty with vengeance. It is a form of retribution with the state acting as the middle person judging the crime according to the level of its severity. The state is in no way seekng retribution as a form of vengeance.

4.8 If society, which is the root cause of the problem, is not reformed, then the death penalty is necessary. It is usually said that it is the crime that causes the perpetrator to be penalized and the perpetrator cannot blame his/her environment or society as being responsible for his/her committing the crime. Other members of society live in the same environment or social context and yet they do not commit the same crimes. Nevertheless, whether society is good or bad does have a significant bearing or whether the death penalty should exist.

If a society enjoys the strengths of sociopolitical structures, education, society and culture, the forces that would motivate a person, other than insanity, to commit a serious crime resulting in capital punishment will be scarce. However, certain negative factors do exist, as in the case of Thailand which abounds in drug problems, vices at both the individual as well as the state level, a lack of discipline and order, unlimited consumerism, smuggled items, the use of influence, a money culture, poverty, and lack of adequate education, for example. These negative factors lead to severe forms of crime and it is only the death penalty that can be used as one way of curbing the crimes. Nevertheless, as long as the problems persist, while capital punishment can help, it may only do so partially. Furthermore, if executions take place quietly without any wide publicity it is likely to be overshadowed by the negative trends in society. People are therefore led to forget the existence of the death penalty and the crime that led to that penalty in the first place.

In such a case, the death penalty becomes the result of the problem and can only act as an instant measure that cannot really solve the problem in a very effective manner. In society life can be too good for people to risk commiting a crime that would lead to a death sentence. Conversely, in a problematic society, life can be so bad as to cause people to risk committing wrongdoing. For 
example, if the cost of drugs is excessvely high, there might be those who would take the grave risk of being sentenced to death if the crime were found out. Other severe results are the risk that many take whereby they cannot avoid the risk of contracting HIV from a sexual relationship which many would do if they were extremely poor or had never received an adequate education.

4.9 The state should not be urged to abolish the death penalty; instead, people should be discouraged from committing crimes that lead to such a penalty. It is a faulty society that necessitates capital punishment since it provides a stimulating environment in that direction. The problem therefore is not with the penalty per se as much as it is the society which is the main contributory factor.

If a country continues to be plagued by negative factors culminating in the imposition of the death penalty, abolition is not the solution as much as the efforts to lessen negative and increase positive factors. The truth is that nobody willingly embraces the death penalty in much the same way that a state is never inclined toward executing its citizens. Large numbers of a population receiving capital punishment are a signal of failure in terms of government, and other state apparatuses must be addressed and remedied. Protective and preventive mechanisms must be instated so that eventually if numbers dwindle and noone receives the penalty, it will automatically come to be abolished on its own. Placing the blame on the existence of these faulty, negative factors in support of the abolition of capital punishment is not correct since it does not mean that the state has failed to teach its people to decipher right from wrong. It does not mean, either, that the majority of the population has the tendency to opt in the direction of wrongdoing. The choice that leads to the ultimate punishment is therefore a personal choice of the individual who is led towards it and he or she must accept the consequences.

4.10 Human rights are not the ultimate value to be used as an excuse to nullify all other values. The human rights argument should be employed only within a specific framework. If it continues to be used indiscriminately, it will deteriorate into a destructive, if not despicable value. Examples would be using it as a moral violation or to do evil as in using the argument of one's rights over one's own body in order to use drugs or to indulge freely in sexual activities. The human rights issue is also used to take advantage of others or to do as one wishes. It is also used for certain benefits as when it has been used so that prisoners end up enjoying living conditions that are better than those of honest yet poor members of society. In such a case, the state's action is the equivalent to giving preferential treatment to a wrongdoer over a good person, both in policy as well as in practice. A prisoner's living conditions have nothing to do with human rights or inhumane treatment; instead, the issue of humanity should be used in connection with the good but poor or destitute to whom the priority of improved living conditions should definitely go. Prisoners shouldn't be given attention simply because the cabinet minister responsible for correction matters deems it appropriate, in the same way that a poor honest person should not be neglected simply because he lacks the ability to gather 
forces to lobby and voice his demands.

4.11 Moral values should not be used as an indicator in the human rights principle. Moral values can indeed be used at several levels as in the argument regarding a life. If one considers one own life from the individual level, life is a precious thing that should be preserved. There is a saying that goes 'to lose one's wealth in order to preserve one's organs and to lose one's organs to preserve a life.' However, if one takes a social or ethical standpoint, that would mean that one must sacrifice one's personal happiness or even one's life for the family, the community or even the country. Indeed, if one were to go further and view the matter in terms of life's highest form of attainment, it would mean the elimination of physical pleasures to lead a contemplative life that leads to the ultimate release from worldly matters.

On the issue of sacrificing one's organs in order to preserve a life, if one were to view it from the point of view of one's society or even the public as a whole, ideally the position of the state is to extend its love and care to its people on an equal basis. It should see to it that their problems as well as their well being are addressed in much the same way as we value our physical organs and care for them in the best way possible. However, if one member of society injures another one directly, or indirectly by violating the rules and regulations that the state has instituted for the benefit of all its members, it is thus obligated to control or even destroy that individual. Indeed, the idea is to preserve the majority: 'if one finger is the problem, sever it.' An organ that causes a disease should be treated if that is possible, but if the disease is so severe that it might spread to the extent that it is beyond treatment, then it would be best that it too should be severed in order to preserve the other parts of the body. A punishment or even a caution in the case of a slight penalty is equivalent to such a treatment. On the other hand, the death penalty which is reserved for severe crimes is the equivalent of a surgical process to preserve the other parts of the body that are still healthy.

According to this thinking, despite the fact that the death penalty is a violation of human rights at the ethical level of the individual, since the penalty is imposed by the state, it is a communual matter. It must therefore be considered according to the ethical level of society or the community as a whole. Indeed, the death penalty preserves the human rights of the community whose members are mostly good, law-abiding citizens by preventing human rights violations at the individual level, which also is a destruction of human rights at the state level. The death penalty is therefore just and in no way a violation of human rights. The correct use of the human rights principle involves caution and avoids confusion. It is important to differentiate between what is a personal matter and what is communual. If it happened that a person was about to use a bomb that would end in the destruction of a large number of people, would allowing him to proceed for the mere reason that killing him would be a human rights violation be a sound argument?

4.12 The human rights craze is one reason for the death penalty. Human rights activists constantly uphold this principle above any other. This is evident in the case 
where these advocates or even countries like the U.S. find every opportunity to attack countries like Thailand on issues related to the freedom to practice religion. The issue concerns certain cultist groups established to preach Buddhist teachings in a way that deviates from the conventional teachings accepted in society and destroys its traditional religion. It could also destroy the values and traditions that society upholds, as in the case of Moonism or the Om Shin Rikiew cult that had to be restricted since cult members posed a threat and were detrimental to the peace and order of society.

The unbridled valorization of human rights can be seen to have reached levels of fanaticism that is being used by the U.S. as a tool to destroy the cultural heritage of other nations. It is an intervention with the intention to impose the tenets of capitalism, free trade and consumerism in other countries for false purposes. The rights are used as an excuse to follow American capitalistic trends. Consumerism has occurred in various countries from the government down to the level of individuals, many of whom are living a hand-to-mouth existence. Vices, sex, fashion and extravagant behavior have meant there are more people who are corrupt and more of them make a living from occupations that destroy other human beings. People view money as a god and it is the fault of consumerism. The human rights issue which should be used as a tool to promote human qualities is instead used as an excuse to destroy the virtue of rules, regulations, discipline and order, being thrifty or even the quality of having empathy towards other human beings and society in general. It is also dictated by one's greed and the tendency to act according to one's whims and desires. All of this attests to the fact that more and more human beings are being enslaved by capitalists. The crime rate rises and the crimes become increasingly heinous. Thailand has had to increase its penalty for drug related crines and impose the death penalty. This was done with the consent of the Thai people which contradicts sharply with what human rights advocates wish. They claim that the death penalty cannot bring down the crime rate. At the same time crimes do not lessen because of a fanatical adherence to human rights. If we were to maintain our faith in religion as fervently as we did in the past, the death penalty might have all but disappeared by this time. Human rights have become a tool for consumerism to destroy other social values. It is also what leads society in the direction of impurity and lustfulness as well as limitless consumption.

4.13 The Lord Buddha preached that enmity can be avoided only by not being vengeful. Some might argue that Thailand is a Buddhist country and Buddhism stresses mercy and forgiveness and therefore the death penalty has no place in this context since it is equivalent to an act of vengeance. The rhetoric of such an argument is incompatible with Buddhist doctrine which stresses that the vengeful party or the giving Ahosikamma, defunct kamma which is an act or thought which has no longer any potential force is the person who has been wronged and not any other party. If a person is killed and another party kills the perpetrator of the crime, the other party who kills isn't taking revenge on the part of the person who was killed in the first place. 
Vengeance cannot be taken on behalf of another person. In this case, the second killer is the person who is causing enmity towards the first killer and whether or not the person who is killed will be vengeful is up to the person killed.

The fact that the state assumes the role of the one imposing capital punishment is not a vengeful act on behalf of anybody. Indeed it is an intervention into the kind of vengeance that is often taken to the extent that it becomes a family feud or village dispute. The state itself is an abstract entity and not a person able to act on the principles of vengeance or revenge. If the state does not proceed in such a way as to ensure that wrongdoing has been punished at a level commensurate to its severity, acts of revenge can occur and the vengeance taken may be even more severe than the crime itself. Penalization by the state is a form of punishment commonly imposed that is just for both the victim and the perpetrator.

\section{Suggestions on Measures Regarding the Death Penalty}

\subsection{Justice and clemency}

The most important argument is the philosophical argument regarding the theories of punishment. The two theories most often used are the theory of retribution and the amendment theory. While the former places emphasis on the justice that the state should provide to both sides, the latter emphasizes clemency towards the penalized. The importance of one theory over the other depends on the priority given. For human rights activists the main concern would be merciful treatment of the penalized person and the amendment theory would be used to support their arguments. In such cases, the point that would be ignored is the concept of justice whereby the state must be responsible for providing equal justice to its citizens as members of society.

From the research and seminars that have been conducted, since justice is an issue that cannot be ignored, the general feeling from the majority of Thai people and academics is that the death penalty should be maintained. The following is a list of points to consider with regard to this subject.

5.1.1 The death penalty should be maintained. However, the penalty should be imposed only in severe cases in order to maintain the principle of justice. Without this guiding principle all other forms of penalty would be affected.

5.1.2 In cases where there is sufficient reason not to impose the death penalty, a lesser penalty should be used. This is already being practised and accords with principles of clemency without sacrificing justice.

5.1.3 In cases where a lesser penalty is imposed as in life imprisonment, a minimum sentence should be stipulated, for example 30 years or more. This is so that the violated party will not feel the justice system has failed to be amply just.

5.1.4 Prison inmates should be given the opportunity to develop morally. This can be done both through learning the dhamma with regards to the issues of life and dhamma practice for serious and continuous spiritual development. Even when an inmate 
receives the death penalty, such teachings should lead the person to a realization of right and wrong and the acceptance that the penalty is a result of his own doing and has been imposed in a just manner. In other words, even if he has led a life of wrongdoing, he will die a better death. It is truly a sign of mercy to see to it that the sentenced person receives the penalty he/she deserves. Other prisoners should also be similarly educated, and emphasis should not be placed only on secular and vocational issues.

5.1.5 It should be stressed that in the case of the death penalty, the aforementioned measures are the best since they guarantee justice and clemency in fair proportion. Indeed it is the most merciful case that a person who has committed a severe crime could receive while still being able to maintain a sense of justice.

5.1.6 The form of execution that causes the least physical pain is yet another demonstration of clemency. This, despite the fact that the person being executed has committed a crime that involves pain and torture of his/her victim.

\subsection{Improvements and amendments of the justice system.}

A faulty justice system is yet another contributory factor in the injustice of the death penalty. Even though the system is not rationally involved with the death penalty or any other penalty and despite the fact that it may be faulty, it is still a necessary process. A faulty system does not justify the abolition of the penalty. It can, however, lead to penalizing an innocent person, bribery or other forms of injustice. It is therefore imperative that amendments be constantly made to rid the system of its faults.

\subsection{Using education to build civilized beings}

Countries in the lead of the movement to abolish the death penalty belong to the group of nations with a well educated and civilized population as in the case of members of the European Union. Education may be one factor contributing to the level of civilization of the population of a country, which also shows less tendency to commit serious crimes aside from factors such as a strong economy, officials who do not adhere to corruption, and a good justice system. After the penalty was abolished, it was not usual for these countries to face problems regarding the justice system since very often there were no cases of those who had to commit severe crimes to the level of deserving the death penalty. In contrast, in less advanced societies such as countries in Asia, conditions differ. For example, some officials take matters in their own hands and perform executions, hence bypassing the justice system or the occurrence of arbitrary acts of vengeance. Not all countries that abolish the death penalty are equivalent in terms of being civilized and enjoying similar levels of peace and prosperity.

It is evident that large nations, for example, the U.S., Japan, China and India, are all considered advanced and civilized yet they are still not able to abolish the death penalty. They attest to the reason why it must be maintained and the reasons are commensurate with a certain society and 
civilization of a country. The reasons that apply to a country with a different social context and civilization may not be applicable. In such countries if the death penalty is abolished, it is done simply as a cover-up gesture that actually masks the killings and executions that go on inside.

The type of education that can preserve and create a civilization and civilized beings so as to build a nation with human resources who are moral and law abiding without neglecting material progress is important. This education should emphasize a good balance between the physical and spiritual, quality and quantity. In terms of quantity, this should derive from one's knowledge and occupation that is carried out in a legitimate manner in major subjects such as knowledge of science, technology and economic value, the kind of material development that does not exploit nature and the human beings who dwell in it and use their mental ability to manage nature for their own well being. The quality aspect places emphasis on religion, art, culture and tradition as well as politics, government and law. This is to say that importance is placed on seeing to it that it creates human beings who are refined in their appreciation of artistic beauty and perceive the merits of goodness. The physical side places emphasis on health and hygience, medical science, a proper diet and a good environment. The spiritual side emphasizes adherance to virtuous principles, the distinction between right and wrong, a moral way of life and applying the intellect in one's thinking process. A balance of these four principles is based on the thinking that a good society is based on the balance between prosperity and virtue.
These main concepts on education will help to improve people so that they end up commiting fewer offences. Thailand is ready to reduce the number of persons who have committed severe crimes that have led them to the death penalty to the extent that it can eventually be abolished. One analogy would be that the death penalty is similar to democracy if urgently imposed while unprepared it will only take effect in name. In actual fact executions still take place between members of society, which means that violations of others' lives are still hardly unusual.

\subsection{Changes in the social environment}

Bad social conditions contribute to society forming its people and providing them with the opportunity to commit wrongdoing. A society proliferating with bad people is one that is open to immorality. A society that abounds in gambling, drug abuse and other forms of vice that incite lustful passions provides opportunities for people to commit the kinds of deeds that are a source of all types of crime. The more people are lured towards materialistic values the more this vice which is a source of enormous sums of money and a gathering of those who are inclined towards corrupt behavior, the more deceptions, assaults, disputes, killings and cheating will occur - to the point that they are accepted as normal practice. This is even more so if the media which is a major source of non-formal education and should be offering the right kind of education, takes part in creating trends and inciting the masses to be lured towards such a defiled lifestyle. Worse still are the commercial 
businesses engaged in enterprises that sell vice that make use of advertising to get people addicted. Crimes are therefore encouraged and result in their proliferation and escalation.

What good would it be to abolish the death penalty that human rights activists usually claim to be a form of violation of the rights of its citizens by the state if these citizens are still violating others' right to life? Moreover, if indeed capital punishment plays a role in controlling the spreading of this violation of the right to life among citizens its abolition is tantamount to promoting such forms of violation that they become more widespread among the people.

\subsection{Changes in economic concepts}

Consumerism has resulted in placing wealth in the hands of a small minority who have become increasingly affluent while the majority of the population have become poorer and increasingly mired in poverty. The latter group are so poor that they do not think of anything other than how to make a living and acquire consumer items. Morality and all other virtues no longer have value and have all but evaporated from people's thinking. Lies, deception, suppression, exploitation, betrayal, and even murder can be committed without a second thought as long as there is a monetary reward involved.

The capitalist economy in Thailand has created two types of poverty: the desperately poor who can hardly fend for themselves and the poor who have turned towards theft or make a living out of peddling vice. The former do not scar their society. As for the latter, while they may be able to generate enough income to escape poverty, the method by which their money is derived is one that corrodes the fabric of society. While capitalism may yield prosperity to its citizens in less developed nations the case is practically the opposite.

It is this economy that paves the way for various forms of crime especially the severe types that result from betrayals in all sorts of shady businesses. Severe forms of punishment must therefore exist to combat such crimes.

As long as this economic climate prevails, attempts to amend factors like society or education will be difficult. Destroying the informal economy, abolishing or reducing vice-related economies, diverting some of the wealth from the rich for the welfare of the poor through the tax system - these are ways to decrease capitalism while increasing socialism, decreasing consumerism while increasing the level of ethics. Measures to generate a greater distribution of wealth will bring down the level of intense crimes while reducing the number of those who face the death penalty.

\section{Conclusion}

The factors regarding whether or not the death penalty should be abolished are dependent upon the social conditions particular to each country. Proceeding with abolition in spite of this consideration would not only be an evasion of the problem under the guise of words like 'developed' or 'civilized', both of which are superficial and mere illusions, but could also contribute to an escalation in the incidence of violent 
crime. This could occur in the absence of adequate preventive measures such as amendments in the judicial system, officient arrests of criminals, and solutions to economic practices that are illegal or perhaps legal but with addictive features.

Capital punishment is not an act of vengeance but a penalty that demands retribution. It is also carried out for the sake of satisfaction like other penalties and not for revenge. This sense of satisfaction is also not merely the satisfaction of the violated party but the satisfaction of society which is considered as agreeing with the penalty being imposed. Without social approval, amendments would have to be undertaken by the legislative system. In the case of Thailand and many other countries, violent offenses committed against other individuals or actions that are detrimental towards society or the general public is an offense towards the system that guarantees the existence of the state. The problems of drugs which destroy members of society, particularly youth, or acts of terrorism which cause destruction to human life, property, security and the credibility of the state, are still prevalent and require no penalty stronger than death, which is a means to eliminate a person's evil deeds permanently. It is also seen as a just act since the perpetrator knowingly chooses to commit the crime. All this despite the fact that the state has offered choices to follow the path of virtue and to avoid choices that lead toward evil or wrongdoing. Since it is at their own free will, these persons should accept the consequences of their actions in the same way as accepting personal responsibility for the violation of a contract.
There is no state except one ruled by a lunatic or one besieged by war, conflict or strife that would willingly see its people executed. Indeed, if capital punishment were not such a necessity, all parties would like to see it abolished. A benevolent state may still be one that imposes the death penalty in cases where it is essential to prevent more violent acts of crime from occurring. In imposing the penalty it must do so with the same level of grief as embittered parents who have to execute their own children.

The heedless transformation of Thailand into a democratic state without adequate preparation has resulted in years and years of confrontation with dictatorships both military and capitalist. Our political system has also been prone to rampant vote buying and politicial cronyism as seen in the present. This same carelessness should not be allowed to recur in the case of the death penalty, since ultimately the praise received from any organization would not be beneficial or offer any lasting solutions to the problems faced by our country. If one is serious in the desire to abolish capital punishment, then one should take haste in solving the crucial problems that are the root cause of the crimes that eventually lead to the death penalty.

\section{References}
Allen, Horry E., and others. 1981. Crime andPunishment. New York: Macmillan.
Bhakapatana, Paradorn. 1978. The Protection of Human Rights on Penalty. Master's Thesis. Chulalongkorn University. [In Thai].


Brisco, Evan. 1999. Death Penalty in USA: An Injured Person in the Advantageous Position. Translated by Nuchanart Naitprasertsri. Unesco Courier 17.10. [In Thai].

Duff, Antony, ed. 1993. Punishment. Brookfield: Dartmouth.

Feinberg, Joel, and Hyman Gross, eds. 1995. Philosophy of Law. London: Wadsworth.

Golding, Martin P. 1981. Philosophy of Law. Englewood Cliffs, New Jersey: Prentice Hall.

Harvey, Peter. 2000. An Introduction to Buddhist Ethics: Foundations, Values and Issues. Cambridge: Cambridge University.

Hood, R. 1993. The Death Penalty a Wide Perspective. Oxford: Clarendon Press.

Horner, I. B. 1967. Early Buddhism and the Taking of Life. Kandy: Buddhist Publication Society.

Jacot/Jacaut, Martin. 1999. Death Penalty is Becoming a Past. Translated by Wanphen Bonggochasathitya. Unesco Courier 17.10. [In Thai]. Jainnanont, Visith. 2003. Death Penalty: An Analysis of Law Enforcement via Injection and Concerned Laws. Master's Thesis. Chulalongkorn University. [In Thai].

Jitsawang, Natthee. 1999. Can Death Penalty Restrain Crimes? Chulasarn Thanthawittaya 1.2. [In Thai].

Jitsawang, Natthee. 2000. Execution by Injection. Bot Pundit 5.1.

Keown, Damien, ed. 2000. Contemporary Buddhist Ethics. London: Curzon Press.

Kraft, K. ed. 1992. Inner Peace, World Peace : Essays on Buddhism and
Nonviolence. New York: State University of New York Press. Mekmanee, Prasert. 1980. Points of Consideration on Capital Punishmest. Bot Pundit 37.3. [In Thai].

Mongkolnawin, Ukrit. 1973. Is Death Penalty Necessary in Thai Society? Warasarn Kotmai 1.1. [In Thai].

Niyomsain, Songkrant. 1958. Execution Procedure Matters. Dulphaha 5.4.

Phromta, Sombharn. 1998. Buddhist Philosophy: Man, Society, and Moral Matters. Bangkok: Faculty of Arts, Chulalongkorn University. [In Thai].

Phanuphong, Ekkarong. 2003. Death Penalty Legend.The Nation Weekend.17 February. [In Thai].

Phanuphong, Ekkarong. 2003. Ayudhaya's 21 Procecures of Execution. The Nation Weekend. 3 March. [In Thai].

Phromta, Sombharn. 1998. Buddhism and Ethic Matters: Prostitution, Abortion, and Mercy Killing. Bangkok: Chulalongkorn University Press. [In Thai].

Phromta, Sombharn. 2003. Man and Religion. Bangkok: Siam Press. [In Thai].

Prokkati, Kittisakdi. 1996. Death Penalty and Ideas Dealing with Freedom of a Person. Rattasatsarn 19.3. [In Thai].

Strithirawisarn, Chaninant. 1980. Capital Punishment. Master's Thesis. Chulalongkorn University. [In Thai].

Suritawongsa, Witthaya. 2000. Human Rights and Death Penalty: Too Late 
to Solve. Warasarn Ratchathan 48.1. [In Thai].

Thepphadolchai, Nantharasmi.2000. How do They Execute Criminals Elsewhere? Warasarn Ratchathan 48.1. [In Thai].

Thongsaeng, Atthasitthi. 2000. Tendencies and Aspects of Death Penalty.

Warasarn Ratchathan 48.1. [In Thai].

Tips, Water E. J. 1998. Crime and Punishment in King Chulalongkorn's Kingdom. Bangkok: White Lotus.

Tripitaka/ The Buddhist Scriptures. 2003. Thai Royal Edition. 45 vols. Bangkok: Department of Religion Affairs. [In Thai].

Ungpraphant, Vithoonya.2000. Execution by Injection. Bot Pundit 5.1. [In Thai]. 